\title{
0710 高分子薄膜/ガラス基板界面のクリープはく離特性
}

\section{Delamination between polymer thin film and glass substrate in creep}

\author{
○横山雅憲 (京大院) 正 平方寛之 (京大工) 正 北村隆行 (京大工)
}

Masanori YOKOYAMA, Hiroyuki HIRAKATA and Takayuki KITAMURA

Department of Engineering Physics and Mechanics, Kyoto University', Kyoto, 606-8501

Key Words: Creep, Delamination, Interface Strength, Crack Growth, Thin Film, Polymer

\section{1.はじめに}

高分子薄膜は, LSI の絶縁層やフォトレジスト, 有機薄膜 トランジスタなどの様々な工業製品として用いられている. これらの高分子薄膜は金属やセラミックスなどの硬い基板 に堆積した構造で用いられることが多い.しかし，その接合 界面の強度は必ずしも十分でなく, 製造プロセス中または使 用中に生に゙るはく離が問題となっている，とくに，高分子材 料は室温でクリープを示すため, 高分子薄膜と基板の界面は クリープによる破壊が生じると考えられる。しかし, 従来の クリープ破壊に関する研究はマクロな均質材に対するもの がほとんどであり，クリープを示す薄膜と基板の界面に対す るクリープ破壊特性は解明されていない. 本研究の最終的な 目的は高分子薄膜のクリープ界面強度を支配する力学法則 を明らかにすることである。

その解明には, まず, クリープによる界面き裂伝ぱ挙動の 観測が不可欠である. 本研究では，その場観察が可能なクリ ープ界面き裂進展試験法を開発し, 厚さがミクロンオーダの エポキシ薄膜とガラス基板の界面に適用した.

\section{2 試験片および試験方法}

試験片および試験システムを図 1 に示す. 本研究では高分 子材としてエポキシ樹脂 (ペルノックスXW-2310) を用いた. 本材は，溶剤で希釈することによって硬化前の粘性を低く $(10 \mathrm{mPa} \cdot \mathrm{s})$ 設定でき, スピンコート法による薄膜化および膜 厚の均一化が容易である. 本材を厚さ $1 \mathrm{~mm}$ のガラス基板上 にスピンコート法で製膜し， $298 \mathrm{~K}$ で 2 時間風乾して溶剤を 揮発させた，その上に，薄膜に負荷を加えるための Si 基板 (厚さ $0.3 \mathrm{~mm}$ ) をおき，ドライオーブン中 $(423 \mathrm{~K}, 1 \mathrm{~h})$ で硬 化させた. 硬化後の膜厚は約 $8 \mu \mathrm{m}$ である. 薄膜の破壊を防 止するため, 基板で挟まれていない部分のエポキシは除去し た。また，ぜい性的な $\mathrm{Si}$ 基板が試験中に破壊することを防 止するため, Si 基板背面にステンレス四角柱を接合した.

ガラス基板を冶具に固定し, 図 1 の負荷点に荷重, $P_{\mathrm{s}}$, に 相当する質量の鍾を懸垂した. $P_{s}$ は予備試験により求めた静 的はく離荷重以下に設定した，き裂進展挙動を詳細に観察す るため，光学顕微鏡による界面き裂のその場観察を行った。 本試験片では基板としてガラスを用いているため, エポキシ /基板宙面を図 1 に示す方向からガラス越しに観察すること が可能である、デジタルカメラを用いた自動撮影システムに より, 試験中の界面の様子を 5 分ごとに撮影した. 負荷, $P_{s}$, を変えた 2 回の試験 (試験片 1 と 2) を, 一定温度下 (298 K), 大気中で行った。

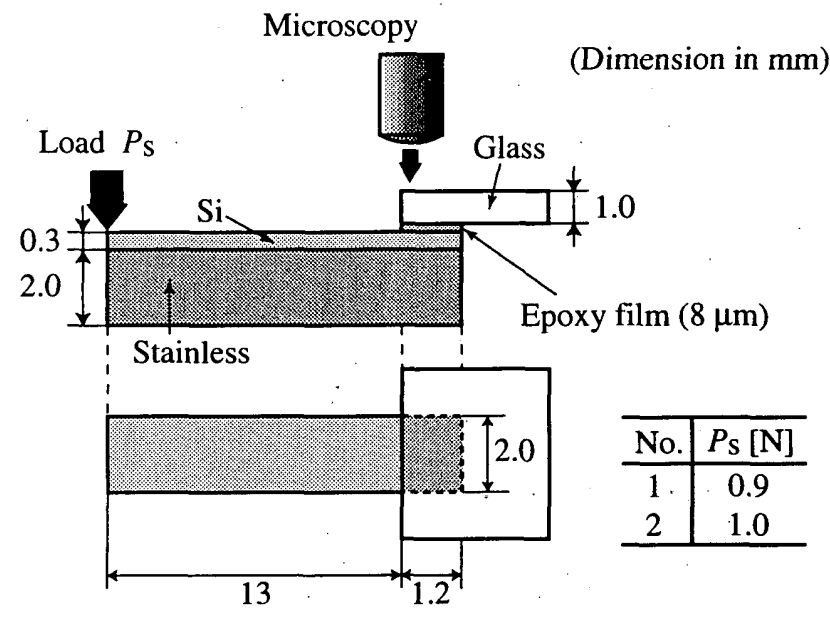

Fig. 1 Specimen and testing system for in-situ creep test

\section{$3^{\bullet}$ 試験結果および考察}

図 2 に試験片 $1\left(P_{s}=0.9 \mathrm{~N}\right)$ のエポキシ膜の光学顕微鏡写 真を経過時間, $t$, ごとに示寸. 試験中に発生したき裂が色 の異なる部分として明瞭に確認でき，時間の経過とともにき 裂が安定進展している様子がわかる.き裂は試験開始直後に 両側のエポキシノガラス界面端角部から発生し, 界面に沿っ て進展した (図 $2(\mathrm{a})) . t=2 \mathrm{~h}$ (図 $2(\mathrm{~b})$ ) では, 両端部から発 生したき裂が合体しており, その後, き裂は試験片全幅で進 展した (図 2 (c), (d)). $t=13.5 \mathrm{~h}$ (図 2 (d)) の直後に, き裂は不 安定進展し全面破断に至った. 試験片 2 のき裂進展挙動も試 験片 1 と同様であった．以上の結果より, 本材 (エポキシ薄 膜/ガラス基板) 界面のクリープき裂伝ぱが存在することが 明らかになった。

クリープき裂進展速度を評価するため, 光学顕微鏡写真を 基にき裂長さ， $a$, を求めた. 図 3 に試験片 1 の $a$ と時間, $t$, の関係を示す。ただし，試験片中央 (I) と端部から $200 \mu \mathrm{m}$ (II) における結果をプロットした. (I)と(II)ともに，き裂は発 生後しばらく減速し，ほぼ一定の速度で進展した後; 加速し て不安定進展に至る。き裂の発生は端部近傍 (I).の方が早く, 遅れて中央部 (II) で発生する，その後，中央部のき裂は大 きく加速し，端部のそれに近づいた後，不安定進展する，き 裂前縁は一様に進展するわけではないので, き裂が進展した 面積を試験片幅 $(2.0 \mathrm{~mm})$ で除したものを平均き裂長さと定 義し, 図中に併せて示す. $a-t$ 線図の全体的な傾向は(I) と(II) のものと同様である。この平均き裂長さと $t$ の関係からき裂 進展速度, $\mathrm{d} a / \mathrm{d} t$, を算出した. 図 4 に, 試験片 1 と 2 の $\mathrm{d} a / \mathrm{d} t$

[No.04-40] 日本機械学会第 17 回計算力学講演会講演論文集〔2004-11.18～20 - 仙台市] 
と $a$ の関係を示す. $\mathrm{d} a / \mathrm{d} t-a$ 関係の概形は試験片 1 と 2 で同 様であり，ほほ一定の速度で進展した後，加速する。 $\mathrm{d} a / \mathrm{d} t$ が一定の領域は, 試験片 1 では約 $0.3 \mathrm{~mm}$, 試験片 2 では約 $0.25 \mathrm{~mm}$ である. また, 荷重, $P_{\mathrm{s}}$, が大きい試験片 2 の方が,
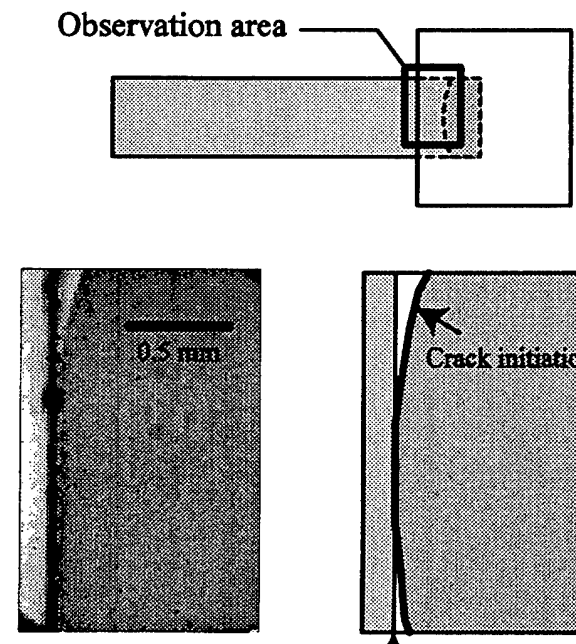

(a) $t=1 \mathrm{~h}$ Edge
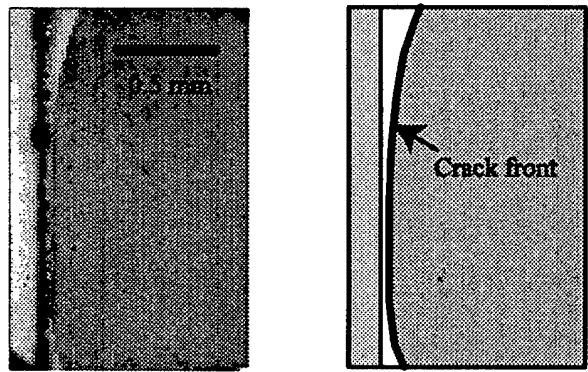

(b) $t=2 \mathrm{~h}$
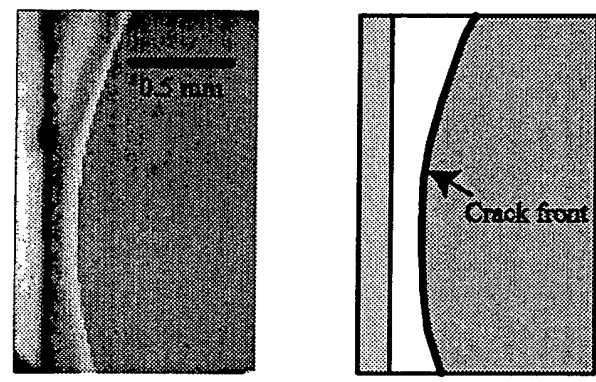

(c) $t=10 \mathrm{~h}$

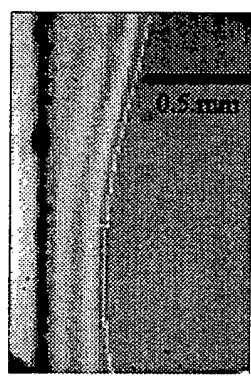

(d) $t=13.5 \mathrm{~h}$

Fig. 2 Interface crack growth behavior in creep test (specimen 1)
き裂進展速度が速い. 本試験では，一定荷重を負荷している ため，き裂が進展するにつれてき裂先端近傍の負荷が高くな る. 伝ぱに伴ってき裂が加速するのはこのためであると考え られる。しかし，本材のクリープき裂伝ぱの支配法則を解明 するには，薄膜のクリープ特性を考慮した解析を行い，き裂 先端近傍の力学状態 (非線形破壊力学パラメータ) を評価す ることが不可欠である.

$$
4 \text { まとめ }
$$

その場観察が可能な高分子薄膜／基板界面のクリープき 裂進展試験法を開発した. 本試験法を厚さがミクロンオーダ のエポキシ薄膜とガラス基板の界面に適応し，クリープき裂 進展速度を実験的に評洒した。今後, 得られた結果を基に非 線形有限要素解析を行い,クリープ界面き裂進を支配する力 学法則について検討する予定である.

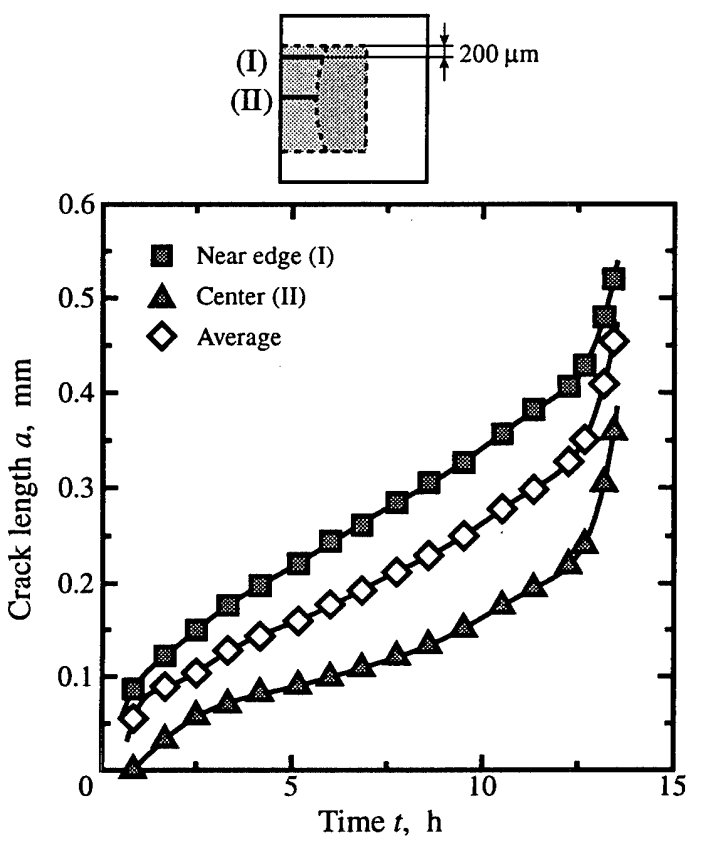

Fig. 3 Relationship between crack length and time in specimen 1

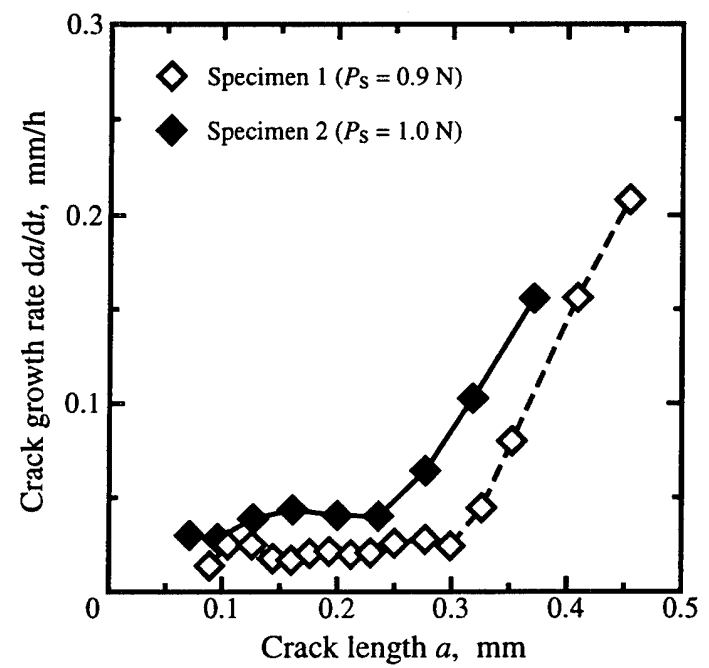

Fig. 4 Relationships between crack growth rate and crack length 